\title{
BEZPIECZEŃSTWO ZBIOROWE A SUWERENNOŚĆ PAŃSTW
}

\section{WPROWADZENIE}

Koniec XIX w. charakteryzował się rozwojem dwóch ważnych dziedzin: prawa międzynarodowego i stosunków międzynarodowych. Pod wpływem idei głoszonych przez organizacje pokojowe i wobec szybko gromadzonych wielkich zapasów broni środowisko międzynarodowe podjęło próbę zniwelowania skutków wojen (coraz bardziej uciążliwych, masowych, odbijających się zarówno na stronach wojujących, jak i na cywilach) przez przyjęcie nowych zasad prawa humanitarnego. Ponadto wojna, dotychczas akceptowana jako prawny instrument polityki narodowej i międzynarodowej państwa, została zakwestionowana w wielu kręgach i narastały żądania, aby całkowicie zakazać wojen. Druga ważna zmiana nastąpiła w strukturze samego środowiska międzynarodowego wraz z pojawieniem się organizacji międzynarodowych, jako nowych zinstytucjonalizowanych form współpracy międzynarodowej. Punkt kulminacyjny obu tych zmian miał miejsce po pierwszej wojnie światowej w 1919 r., kiedy utworzono Ligę Narodów jako instytucję mającą na celu utrzymanie międzynarodowego pokoju, zgodnie z ideą bezpieczeństwa zbiorowego. Jednak ogólnie uważa się, że statut Ligi Narodów stanowił raczej ułomną próbę realizacji koncepcji systemu bezpieczeństwa zbiorowego.

Koncepcja bezpieczeństwa zbiorowego odnosi się do wspólnych działań państw w czasie pokoju w celu utrzymania trwałego pokoju i zapewnienia wzajemnej obrony. Zbiorowe bezpieczeństwo opiera się zatem na zasadzie, że wszystkie państwa członkowskie systemu są zobowiązane do udzielenia pomocy, jeżeli jedno z nich zostaje zaatakowane lub zagrożone przez obce siły. Ponadto inna zasada bezpieczeństwa zbiorowego zakłada konieczność zapewnienia, że państwa członkowskie zobowiązują się do wypowiadania wojny każdemu państwu dopuszczającemu się aktu agresji. Tym, co wyróżnia regionalne sojusze bezpieczeństwa zbiorowego, jest to, że zagrożenie jest mniej lub bardziej precyzyjnie zdefiniowane. Jest ono także rozproszone i niepewne, więc instytucja zbiorowego bezpieczeństwa może w imię zapobiegania konfliktom przyjąć do swojego grona państwa członkowskie, które niekoniecznie mają te same intencje czy też ideologię, a nawet mogą stanowić zagrożenie dla innych podmiotów. Zbiorowe bezpieczeństwo uwzględnia więc szerokie członkostwo w celu zapobiegania konfliktom przez konsultacje i zdecydowaną reakcję wojskową w razie naruszenia pokoju i bezpieczeństwa międzynarodowego. Liga 
Narodów i Organizacja Narodów Zjednoczonych są klasycznymi przykładami prób tworzenia systemu bezpieczeństwa zbiorowego, choć warunki i okoliczności ich powstania były różne.

W ten sposób bezpieczeństwo państw wiąże się z tworzeniem tradycyjnych sojuszy wojskowych, w których państwa zobowiązują się bronić siebie nawzajem $\mathrm{w}$ razie ataku na jednego $\mathrm{z}$ członków tego sojuszu. Określamy to jako samoobronę zbiorową. $\mathrm{Z}$ jednej strony tworzenie systemu bezpieczeństwa zbiorowego, bardziej nastawionego na prewencję, jest skierowane do wszystkich, łącznie z członkami systemu. Ten ostatni charakteryzuje wojskowe przygotowania do wspólnej obrony, jak również to, że jest środkiem odstraszania. Dla niektórych zbiorowe systemy obrony przynoszą pozytywne wyniki w tym sensie, że utrzymują stan trwałego spokoju. Niemniej sytuacja ta prowadzi do zwiększenia napięć, co może wywołać wyścig zbrojeń i niemal stałe utrzymywanie stanu niepewności. Z drugiej strony bezpieczeństwo zbiorowe różni się radykalnie od samoobrony zbiorowej w tym sensie, że zakłada, iż żadne państwo nie może osiagnąć pełnego bezpieczeństwa przez działania jednostronne.

Kolejna cechą charakterystyczną systemu bezpieczeństwa zbiorowego jest to, że zazwyczaj powstaje on również na gruncie organizacji regionalnych, pomimo że świat doczekał się powstania dwóch organizacji międzynarodowych o charakterze powszechnym: nieistniejącej już Ligi Narodów (w Genewie) oraz obecnie funkcjonującej Organizacji Narodów Zjednoczonych (w Nowym Jorku), która ma monopol w zakresie bezpieczeństwa zbiorowego. Postrzegany w ten sposób system bezpieczeństwa zbiorowego powstaje na gruncie porozumień o wspólnej obronie między państwami członkowskimi, dysponującymi silna armią, przygotowaną $\mathrm{w}$ tym celu. Rozwiązywanie kwestii bezpieczeństwa zbiorowego na gruncie organizacji regionalnych zostało przewidziane i podkreślone w Karcie Narodów Zjednoczonych; stosowne postanowienia zawarto w rozdziałach VI i VIII tejże Karty. Zaleca się w nich, aby państwa szukały rozwiązania konfliktów wewnątrz struktur przewidzianych przez regionalne agencje lub istniejących traktatów regionalnych, zanim zwrócą się w tej materii do Rady Bezpieczeństwa ONZ. W ramach tych regionalnych układów bezpieczeństwa podstawowe obowiązki państw członkowskich wynikają ze wzajemnej oceny bezpośredniego zagrożenia i kwestii bezpieczeństwa z nim związanego. Zobowiązania te wynikają również z jakości dialogu pomiędzy państwami członkowskimi. Proces ten jest ułatwiony, jeżeli członkowie mają takie same poglądy ideologiczne. Jeśli nie da się pogodzić punktów widzenia, zwłaszcza na poziomie ideologicznym, zachowanie bezpieczeństwa zbiorowego zależy od jakości dialogu, jego przejrzystości i ciagłości. Niektóre z tych działań, następujące w ramach wymiany często radykalnie odmiennych poglądów, moga jednak doprowadzić do porozumień, które mogłyby zapobiegać eskalacji napięć. Po zakończeniu zimnej wojny w wielu kwestiach wojskowych i międzynarodowych zbiorowe bezpieczeństwo nabrało nowego znaczenia. Ponadto ewolucja NATO od 1949 r., jako organizacji samoobrony zbiorowej, odzwierciedla jej trwałość i zdolność do bycia prawdziwą organizacją bezpieczeństwa zbiorowego, mogąca zapewnić wspólną obronę. Dysponuje ona bowiem dobrze zorganizowaną armią, zdolną do skutecznego działania. Jak na ironię, koniec zimnowojennej rywalizacji nie spowodował złagodzenia napięć. Zamiast tego byliśmy i jesteśmy 
świadkami eksplozji wewnątrzpaństwowych konfliktów i wojen domowych w wielu krajach, takich jak: Jugosławia, Bośnia i Rwanda, czy obecnie Somalia, Afganistan i Syria, w których właśnie ludność cywilna jest główną ofiara przemocy w czasie konfliktów. Czy to oznacza, że jesteśmy świadkami końca misji ONZ, czy raczej jest to tylko chwilowa słabość, która wymaga jedynie stosunkowo prostych zmian lub zdecydowanego działania społeczności międzynarodowej? Na to pytanie nie ma jednoznacznej odpowiedzi - problem pozostaje nierozwiązany. ONZ jest jedyną organizacją bezpieczeństwa zbiorowego o zasięgu uniwersalnym. W realizacji swojej misji ONZ mogła liczyć na struktury regionalne, np. Unię Afrykańską, która nie jest jednak na tyle dobrze zorganizowana, by skutecznie uporać się z problematyką utrzymania pokoju, bezpieczeństwa i stabilności ${ }^{1}$.

\section{POJECIE, ISTOTA I ZNACZENIE BEZPIECZEŃSTWA ZBIOROWEGO}

Zagadnienie bezpieczeństwa jest jednym $\mathrm{z}$ najczęściej omawianych na gruncie interdyscyplinarnym - bywa definiowane na gruncie różnych nauk humanistycznych, ekonomicznych, czy też prawnych ${ }^{2}$. W związku z tym wypracowanie jednoznacznie brzmiącej definicji pojęcia bezpieczeństwa jest rzeczą trudną, czy wręcz niemożliwą. Niemniej przy próbie definicji pojęcia bezpieczeństwa zbiorowego należy uwzględnić wszelkie różnorodne ujęcia, które zrodziły się w obrębie wielu nauk. System bezpieczeństwa zbiorowego odnosi się bowiem do wszystkich zagadnień życia politycznego i społeczno-gospodarczego oraz kulturalnego społeczności międzynarodowej. Z tej perspektywy można ujać system bezpieczeństwa zbiorowego jako zinstytucjonalizowaną formę przygotowania się do legalnego użycia siły w celu zapewnienia trwałego pokoju, bezpieczeństwa i stabilności. Definicja pojęcia „bezpieczeństwo zbiorowe” autorstwa H. C. Johnsona i G. Niemeyera, choć zasadniczo oddaje istotę zagadnienia, to jednak nie wydaje się, że uwzględnia zmiany, które zaszły na arenie międzynarodowej ${ }^{3}$. Współcześnie bowiem

${ }^{1}$ Zob. J. Cardona Liorens, La cooperation entre les Nations Unies et les accord et organismes regionaux pour le reglement pacifique des affaires relatives au maintien de la paix et de la securite internationales, w: Boutros Boutros Ghali amicorum discipulorumque liber. Paix, developpement, democratie, t. 1, Bruxelles 1998, s. 251-289.

${ }^{2}$ Szerzej zob. R Zięba, Pojęcie $i$ istota bezpieczeństwa państwa $w$ stosunkach międzynarodowych, „Sprawy Międzynarodowe” 1989, nr 10, s. 49; o kwestii bezpieczeństwa i jej wielowątkowości zob. K. Żukrowska (red.), Bezpieczeństwo międzynarodowe. Przeglad aktualnego stanu, Warszawa 2011, s. 15-34; D. Mierzejewski, Bezpieczeństwo europejskie w warunkach przemian globalizacyjnych, Toruń 2011, s. 32; zob. R. Zięba, Teoria ogólna bezpieczeństwa państwa w stosunkach międzynarodowych, w: Stosunki międzynarodowe w XXI wieku. Księga jubileuszowa z okazji 30-lecia Instytutu Stosunków Międzynarodowych UW, Warszawa 2006, s. 936-939.

${ }^{3}$, ,[A] system based on universal obligation of all nations to join forces against an aggressor state as soon as the fact of aggression is determined by established procedure. In such system, aggression is defined as a wrong in universal terms and an aggressor, as soon as he is identified, stands condemned. hence, the obligation of all nations to take action against him is conceived as a duty support right against wrong. It is equally founded upon the practical expectation that a communal solidarity of all nations 
zagrożenia międzynarodowego pokoju i bezpieczeństwa nie powstaja jedynie ze strony państw, ale również ze strony innych podmiotów niepaństwowych. R. Zięba słusznie zwraca uwagę na fakt, że istota bezpieczeństwa zbiorowego sprowadza się do polityczno-militarnego zapewnienia względnego pokoju państwom oraz ewentualnej reakcji w celu obrony napadniętego lub zagrożonego napaścią państwa. Gwarancja ta jest oparta w dłużej mierze na potencjale wojskowym i gospodarczym ${ }^{4}$.

System bezpieczeństwa zbiorowego, rozwijający się na przestrzeni wieków, może być pojmowany jako zinstytucjonalizowany, uniwersalny lub regionalny, w którym państwa w traktacie wielostronnym uzgodniły konieczność współdziałania przeciwko jakiejkolwiek agresji, napaści lub innemu bezprawnemu użyciu siły przez któreś z państw systemu członkowskiego. W związku z tym koncepcja bezpieczeństwa zbiorowego jest skierowana przede wszystkim przeciwko bezprawnemu użyciu siły w obrębie grupy państw członkowskich, tworzących wspólny system bezpieczeństwa, rzadziej - przeciw zagrożeniu zewnętrznemu.

Jako zinstytucjonalizowaną formę współpracy państw lub jako organizację międzynarodową system bezpieczeństwa zbiorowego należy odróżnić od tradycyjnych sojuszy lub koalicji politycznych. Tradycyjne sojusze obronne i systemy bezpieczeństwa zbiorowego mają na celu unikanie międzynarodowych konfliktów zbrojnych, a szczególnie tłumienie potencjalnych aktów agresji przeciw jednemu z państw członkowskich, są jednak między nimi istotne różnice. Tylko system bezpieczeństwa zbiorowego jest oparty na nielegalności użycia siły przez poszczególne państwa lub grupy państw, z wyjątkiem wypadków samoobrony lub zastosowania siły dozwolonej przez sam system bezpieczeństwa. Jednakże użycie siły w celu samoobrony przez państwo, które jest obiektem ataku zbrojnego, jest prawnie uzasadnionym środkiem doraźnym jedynie do momentu, kiedy zadziałaja mechanizmy bezpieczeństwa zbiorowego w celu obrony państwa będącego obiektem ataku.

Kolejną istotną różnica pomiędzy tradycyjnymi sojuszami a systemem bezpieczeństwa zbiorowego jest fakt, że chociaż jedne i drugie są oparte na prawnie wiążących umowach lub traktatach międzynarodowych, zobowiązania ponoszone przez państwa członkowskie sojuszu są bardziej ograniczone i maja mniejszy wpływ na prawa państw suwerennych aniżeli zobowiązania narzucone na państwa członkowskie systemu bezpieczeństwa zbiorowego. Tak więc to właśnie poszczególne państwa członkowskie sojuszu muszą stwierdzić, czy rzeczywiście doszło do aktu agresji przeciwko innemu państwu członkowskiemu sojuszu i jakie działania powinny zostać podjęte. Natomiast w systemie bezpieczeństwa zbiorowego to jakiś organ międzynarodowy stwierdza, czy doszło do aktu agresji, i decyzje tego organu międzynarodowego są teoretycznie uważane

would from the outset make it clear to every government that aggression does not pay" (H. C. Johnson, G. Niemeyer, Collective Security: The Validity of an Ideal, „International Organization” 8, 1954, nr 1, s. 19-20). Zob. P. G. Danchin, Things Fall Apart: The Concept of Collective Security in International Law, w: P. G. Danchin, H. Fisher (red.), United Nations Reform and the New Collective Security, University of Maryland School of Law Legal Studies Research Paper Series, Cambridge 2009, s. 4.

${ }^{4}$ Zob. R. Zięba (red.), Bezpieczeństwo międzynarodowe po zimnej wojnie, Warszawa 2008, s. 19. 
za prawnie wiążące. Niemniej ta różnica staje się mniej kategoryczna i mniej wyraźna, jeśli weźmie się pod uwagę nowoczesne rodzaje sojuszy. Te nowoczesne rodzaje sojuszy (takie jak np. Organizacja Paktu Północnoatlantyckiego [NATO] lub niegdyś Układ Warszawski) są także wysoce zinstytucjonalizowane i zazwyczaj zapewniaja procedury podejmowania decyzji, które przynajmniej teoretycznie mogą zaowocować postanowieniami mającymi podobny efekt jak postanowienia odpowiednich organów systemu bezpieczeństwa zbiorowego. Yoram Dinstein pisze chyba słusznie, że zdanie zawarte w art. 51 Karty Narodów Zjednoczonych nie jest jednoznaczne, można je interpretować znacznie szerzej ${ }^{5}$.

Inną cechą charakterystyczną bezpieczeństwa zbiorowego, w przeciwieństwie do sojuszy, jest to, że system bezpieczeństwa zajmuje się przede wszystkim utrzymaniem pokoju i bezpieczeństwa zbiorowego w obrębie grupy państw tworzących społeczność międzynarodową. Jego naczelnym celem jest powstrzymanie aktu agresji jednego z państw na inne państwo. Ma to być osiaggane przez użycie lub groźbę użycia połączonych sił zbrojnych wszystkich państw członkowskich przeciwko rzeczywistemu lub potencjalnemu agresorowi. Natomiast utrzymanie pokoju przez sojusz jest realizowane przez odstraszanie potencjalnego agresora spoza sojuszu albo przynajmniej przez zachowanie równowagi sił pomiędzy konkurującymi sojuszami. Jednakże po raz kolejny należy zwrócić uwagę na to, że nowoczesne sojusze przejęły podobne obowiązki pod tym względem. Tak więc w praktyce te teoretyczne różnice pomiędzy systemami bezpieczeństwa zbiorowego a sojuszami trochę się zacierają ${ }^{6}$.

5 ,The phrase individual or collective self-defence, as used in Article 51 of the Charter of the United Nations, is not easily comprehensible. A close examination of the text, in light of the practice of States, shows that more than a simple dichotomy is involved" (Y. Dinstein, War, Agression and Self-defence, Cambridge 2004, s. 222). Prawo państw do korzystania z siły w celu samoobrony przed atakami z zewnątrz jest ugruntowane normą międzynarodowego prawa zwyczajowego. Karta Narodów Zjednoczonych również w art. 51 podkreśla przyrodzone prawo państw do samoobrony.

${ }^{6}$ Należy zasadniczo odróżnić system bezpieczeństwa zbiorowego od systemu samoobrony zbiorowej. System bezpieczeństwa zbiorowego odnosi się do współpracy państw na zasadach solidarności i wzajemnego wspierania się w procesie utrzymania trwałego pokoju i stabilności na arenie międzynarodowej. Głównym celem systemu bezpieczeństwa zbiorowego jest utrzymanie pokoju, zapobieganie i usuwanie zagrożenia pokoju i bezpieczeństwa międzynarodowego, a także skuteczne reagowanie w razie aktu agresji (w wypadku ONZ problematyka ta jest uregulowana zgodnie z postanowieniami rozdz. VII Karty NZ). Państwa będące uczestnikami systemu bezpieczeństwa zbiorowego w drodze kompromisu politycznego wyrażonego w formie umowy wielostronnej przyjmują zasady, formy i środki do wspólnego działania na rzecz utrzymania pokoju i bezpieczeństwa międzynarodowego. To właśnie określamy jako zinstytucjonalizowanie legalnego użycia siły przez państwa, czyli system bezpieczeństwa zbiorowego, który umożliwia państwom członkowskim szybkie i sprawne podejmowanie decyzji politycznych i militarnych. Współcześnie klasyczny przykład systemu bezpieczeństwa zbiorowego funkcjonuje w ramach ONZ. Natomiast system zbiorowej obrony (inaczej samoobrona zbiorowa) tworzy grupa państw, która na podstawie wspólnych ustaleń powołuje organizację o charakterze sojuszu polityczno-wojskowego. Głównym celem działania owej organizacji jest obrona jej poszczególnych członków przed zagrożeniem z zewnątrz mniej lub bardziej zidentyfikowanym. Klasycznym przykładem systemu zbiorowej obrony jest Organizacja Paktu Północnoatlantyckiego (NATO). Zgodnie z jej statutem każde państwo członkowskie zobowiązuje się do aktywnego działania w celu rozwijania pokojowych i przyjaznych stosunków między członkami oraz do pełnej gotowości odparcia jakiejkolwiek agresji wobec jej członków. 


\section{POJECIE SUWERENNOŚCI W ŚWIETLE PRAWA MIËDZYNARODOWEGO}

Suwerenność państw jest jednym z podstawowych pojęć prawa międzynarodowego, rozumianym jako niezależność państwa wynikająca z posiadania pełnej podmiotowości prawnomiędzynarodowej ${ }^{7}$. Z suwerenności wynika zatem możliwość nieskrępowanej władzy państwowej do podejmowania wszelkich działań w interesie jego obywateli. Na przestrzeni lat definicja suwerenności uległa znacznemu uproszczeniu, czy raczej uściśleniu, ze względu na daleko idąca współzależność pomiędzy uczestnikami stosunków międzynarodowych. Rosnąca liczba państw (obecnie 193) ${ }^{8}$, coraz większa rola niepaństwowych uczestników stosunków międzynarodowych, niemożność faktycznego samodzielnego funkcjonowania państwa (jako rezultat daleko idącej integracji w sferze politycznej, gospodarczej i społeczno-kulturowej, a zwłaszcza na szczeblu regionalnym) stały się przyczyną zmiany podejścia do klasycznej definicji pojęcia suwerenności. Dlatego współcześnie suwerenność pojmuje się jako zdolność podmiotu prawa międzynarodowego do sprawowania zwierzchnictwa nad określonym terytorium i określoną ludnością ${ }^{9}$. Wyrazem suwerenności jest również korzystanie w pełni z czynnego i biernego prawa legacji, ius contrahendi, ius tractatum itp. - określanych mianem atrybutów podmiotowości prawnomiędzynarodowej ${ }^{10}$. W literaturze prawnomiędzynarodowej wyraźnie podkreślono to, co jest władzą zwierzchnią, samodzielnie decydująca

\footnotetext{
${ }^{7}$ Można powiedzieć, że suwerenność to uprawnienia przyznane państwu i uznane przez podmioty prawa międzynarodowego, oznaczające samodzielność, niezależność, brak podlegania kontroli zewnętrznej, chyba że wynika ona ze zobowiązań międzynarodowych. W tym kontekście suwerenność państwowa zakłada wyłączność kompetencji na władzę ustawodawczą, wykonawczą i sądowniczą. W praktyce suwerenność państwowa jest ograniczona przez proces globalizacji gospodarczej, kulturowej i politycznej. Swobodny przepływ osób i kapitału wymaga od państwa uwzględnienia regionalnych i międzynarodowych uwarunkowań, w których funkcjonuje. W literaturze i doktrynie prawa międzynarodowego, a także w orzecznictwie dominuja tendencje opisu problematyki suwerenności państw w kontekście zwierzchnictwa nad określonym terytorium i nad jego ludnością, a nie zdolności do skutecznej obrony owego terytorium, czy też owej ludności. Należy zwróć uwagę, że Konwencja z Montevideo z 1933 r. o prawach i obowiązkach państw wyraźnie podkreśla zdolność władzy państwowej do funkcjonowania na arenie międzynarodowej niezależnie od innego podmiotu jako atrybut podmiotowości prawnomiędzynarodowej, tyle tylko, że istotne jest to, co oznacza pojęcie „,niezależność” w dobie globalizacji. Suwerenność jest zagadnieniem złożonym i wielopłaszczyznowym, dlatego trudno je jednoznacznie zdefiniować. W prawie międzynarodowym również nie ma wyczerpującej definicji suwerenności. Szerzej na ten temat zob. L. Ehrlich, Prawo narodów, Kraków 1958; M. N. Shaw, Prawo międzynarodowe, Warszawa 2000; I. Wierzchowska, Suwerenność państwowa $w$ prawie międzynarodowym, w: I. Gawłowicz, I. Wierzchowska (red.), Koncepcje suwerenności - zbiór studiów, Warszawa 2005; Karta Narodów Zjednoczonych z 26 czerwca 1945 r. (Dz. U. 1947, Nr 23, poz. 90 ze zm.); R. Kwiecień, Suwerenność państwa, rekonstrukcja i znaczenie idei $w$ prawie międzynarodowym, Warszawa 2004; D. Mierzejewski, Bezpieczeństwo a problem suwerenności państw we wspótczesnym świecie, w: Z. Leszczyński, S. Sadowski (red.), Suwerenność państwa we wspótczesnych stosunkach międzynarodowych, Warszawa 2005, s. 107.

${ }^{8}$ Biorąc pod uwagę liczbę państw pełnoprawnych członków Organizacji Narodów Zjednoczonych.

${ }^{9}$ Szerzej zob. T. Łoś-Nowak, Państwo jako uczestnik stosunków międzynarodowych, w: A. W. Jabłoński, L. Sobkowiak (red.), Studia z teorii polityki, Wrocław 1998.

10 Zob. T. Łoś-Nowak, Wstęp do teorii stosunków międzynarodowych, Poznań 1999; L. Ehrlich, Prawo narodów, Lwów 1932; idem, Prawo narodów, Kraków 1947.
} 
o zakresie i kierunku swojego działania ${ }^{11}$ oraz państwo jako podmiot prawa międzynarodowego, niezależne od innych podmiotów, charakteryzujące się dobrowolnością w nawiązywaniu stosunków międzynarodowych o charakterze gospodarczym, politycznym i społeczno-kulturalnym oraz samodzielnością w kształtowaniu swojego ustroju społeczno-gospodarczego i politycznego ${ }^{12}$.

W prawie międzynarodowym pojęcie suwerenności jest jednoznaczne z podmiotowością prawnomiędzynarodową. Pomimo próby daleko idącej relatywizacji tego pojęcia na gruncie różnych dziedzin nauki z punktu widzenia prawa międzynarodowego pozostaje absolutnym atrybutem państwowości i podstawowym pojęciem systemu prawa międzynarodowego. Suwerenność w ujęciu prawniczym jest pojęciem całościowym, a więc niepodzielnym i niepodlegającym stopniowaniu ${ }^{13}$. Zgadzam się z poglądem wyrażonym przez niektórych przedstawicieli nauki prawa międzynarodowego, a zwłaszcza Jerzego Tyranowskiego, że nie istnieje utrata suwerenności, z prawnego punktu widzenia można bowiem mówić jedynie o ograniczeniu wykonywania suwerenności. Najczęściej następuje to w drodze dobrowolnego przystapienia do umów dwustronnych albo wielostronnych $\mathrm{w}$ ramach przystapienia do organizacji międzynarodowych, a zwłaszcza organizacji o charakterze integracyjnym (np. Unia Europejska) ${ }^{14}$. Zjawisko dobrowolnego ograniczenia wykonywania suwerenności musi mieć zatem charakter względny i odwołalny. Dlatego, moim zdaniem, błędem jest wprowadzanie pojęcia „utrata suwerenności” w literaturze przedmiotu. Wzajemne powiązania poszczególnych państw w różnych dziedzinach i na różnych szczeblach życia społeczno-gospodarczego i politycznego w żaden sposób nie zmieniaja prawnego charakteru suwerenności i jej istoty $\mathrm{w}$ odniesieniu do państw, jako fundamentalnej przesłanki ich istnienia. Suwerenność pozostaje zatem podstawową zasada i pojęciem prawa międzynarodowego oraz najważniejszym atrybutem państwa. Dzięki niemu jest ono podmiotem uprzywilejowanym i zasadniczo różniącym się od innych podmiotów.

\footnotetext{
11 Szerzej zob. L. Antonowicz, Podręcznik prawa międzynarodowego, Warszawa 2006, s. 21.

12 Rzeczywiście, według O. Beauda: ,la souveraineté interne et la souveraineté externe s’expriment par des prérogatives juridiques différentes. La souveraineté interne se manifeste par des actes unilatéraux qui traduisent un rapport de subordination entrel'auteur et l'adressatairede la norme, alors que la souveraineté internationale recourtà des actes juridiques bilatéraux ou plurilatéraux (traités, coutumes) qui requièrent le consentement du destinataire de la norme" (O. Beaud, La notion d'État, w: Vocabulaire juridique fondamental du droit, „Archives de philosophie du droit” 35, 1990, s. 131). Podobnie J. Kranz pisze, że: ,[l]es notions de souveraineté de l'État et de souveraineté populaire étant distinctes, elles restent néanmoins dans un certain rapport. [...] Cependant, selon le droit international, la suppression de la souveraineté populaire n'aboutit pas automatiquement à la disparition de la souveraineté de l'État" (J. Kranz, Réflexionssur la souveraineté, w: Theory of International Law at the Threshold of the 21st Century. Essays in Honour of K. Skubiszewski, Kluwer Law International, 1996, s. 205-206).

${ }^{13}$ Szerzej zob. J. Tyranowski, Suwerenność i kompetencja własna państw a integracja europejska, w: E. Małuszyńska, B. Gruchman (red.), Kompendium wiedzy o Unii Europejskiej, Warszawa 2012, s. 30.

${ }^{14}$ Zasada ograniczenia wykonywania suwerenności oznacza w świetle prawa międzynarodowego ograniczenie kompetencji wyłącznej państwa w różnych sferach, wynikające z postanowień wielu statutów organizacji międzynarodowych (np. Pakt Ligi Narodów w art. 15 ust. 8 czy też Karta Narodów Zjednoczonych - art. 2 ust. 7).
} 


\section{SUWERENNOŚĆ \\ JAKO ZASADA PRAWA MIĘDZYNARODOWEGO}

Zasada suwerenności jest ściśle związana ze współczesnym państwem, i to już od XVII w. ${ }^{15}$ Stanowiła ona bowiem odpowiedź na wojny religijne, które zniszczyły Europę. W wyniku tych doświadczeń rodziła się zasada, według której religia władcy jest religia narodu (cuius regio eius religio). Aby uniknąc niszczycielskich konfliktów wojennych, postanowiono w ramach traktatu westfalskiego, że żadne państwo nie powinno ingerować w wewnętrzne sprawy innego. Od tamtego okresu zasada ta obowiązuje w stosunkach międzynarodowych, oczywiście nie stosowano jej w czasach pozaeuropejskich podbojów, które miały miejsce do XX w.

Współcześnie zasada suwerenności państw jest uznana za fundament obowiązującego systemu prawa międzynarodowego, czego wyrazem jest jej zawarcie w Karcie Narodów Zjednoczonych. Problematyka suwerenności jest podkreślana również na gruncie wewnętrznego porządku prawnego poszczególnych państw. Zasada odpowiedzialności za ochronę (Responsibility to protect - R2P) jako nowa inicjatywa społeczności międzynarodowej w międzynarodowym porządku prawnym, już dzisiaj uznawana jest za istotne ograniczenie zasady suwerenności państw. Chociaż istnieja słuszne powody krytykowania eurocentrycznej wizji suwerenności, to jednak doprowadziła ona do powstania nowoczesnych norm $\mathrm{w}$ tym zakresie, które stały się między-

${ }^{15}$ Zagadnienie suwerenności od dawna stanowiło istotny element normalizacji stosunków zewnętrznych i wewnętrznych pomiędzy poszczególnymi podmiotami, czego wyrazem jest podkreślenie jej znaczenia na gruncie doktryny filozoficznej, prawnej oraz politologicznej. Zainteresowanie problematyką suwerenności i zmiany w rozumieniu tego pojęcia można zaobserwować w koncepcjach filozoficznych takich myślicieli, jak: J. Bodin, H. Grocjusz, T. Hobbes, J. J. Rousseau czy J. Lock, choć należy podkreślić, że koncepcja suwerenności J. Bodina z XVI w., dotycząca suwerenności władzy mającej nad sobą jedynego Boga, uległa znacznemu uściśleniu (zob. J. Bodin, Sześć ksiag o Rzeczypospolitej, PWN, Warszawa 1958); E. Haliżak, R. Kuźniar, J. Symonides (red.), Globalizacja a stosunki międzynarodowe, Bydgoszcz-Warszawa 2003. Należy wspomnieć, że pojęcie suwerenności jest stale w centrum debaty dotyczącej rozwoju prawa międzynarodowego - chociaż tradycyjnie tworzone było w paradygmacie prawa i wyłącznie do regulowania stosunków między państwami, a tym samym zapewnienia ich pokojowego współistnienia. Prawo międzynarodowe służy realizacji różnych celów. Kolejne zmiany priorytetów wiążą się z obawami społeczności międzynarodowej i ewolucją paradygmatów. Jeśli pojęcie paradygmatu obejmuje koncepcje, teorie, przedstawicielstwa i wartości, które pozwalają nam zrozumieć i zinterpretować rzeczywistość społeczna, to ewolucja pojęcia suwerenności jest chyba najczęściej używanym koncepcyjnie instrumentem międzynarodowego porządku prawnego, nie tylko wyjaśniającym zjawiska społeczne, lecz także je kształtującym. Ta funkcja suwerenności wyjaśnia również zainteresowanie problematyką, dlatego kontynuuje się te rozważania i nadal poświęca się jej wiele miejsca w pracach z zakresu prawa międzynarodowego publicznego. Jednak podejmowane badania nad tym specyficznym systemem prawnym, charakteryzującym się zdecentralizowaną strukturą społeczności międzynarodowej, którą ma porządkować, skutkują tym, że suwerenność pojawia się jako najdoskonalszy instrument we wzajemnych stosunkach istniejących w tym szczególnym porządku prawnym. Suwerenność jest kwestią stale budząca zainteresowanie doktryny. Atrakcyjność koncepcji suwerenności wynika z konieczność refleksji na ten temat. Suwerenność jest jednocześnie przeklinana i czczona. Przeklinaja ją ci, którzy widzą w niej przestarzałe pomysły, niezgodne z realiami społeczeństwa międzynarodowego i przyczynę wszelkich słabości prawa międzynarodowego. Dlatego pojęcie to powinno - ich zdaniem - zniknąć raz na zawsze. Jest to także jedna z najbardziej szanowanych koncepcji i zasad prawa międzynarodowego, uznawanych za niezbędne i istotne dla niepodległości narodów, za fundament całego systemu międzynarodowego porządku prawnego. Stąd tak wielkie jej znaczenie. 
narodowymi standardami. Suwerenność to jedna z podstawowych zasad prawa międzynarodowego i stosunków międzynarodowych, wyrażona jako niezbywalna cecha państwowości i zarazem jedno z kryteriów odróżniające państwa od innych podmiotów. Jest ona obecna $\mathrm{w}$ wielu aktach prawnomiędzynarodowych, stanowiących podstawę ładu międzynarodowego ${ }^{16}$. W interesie współczesnego życia międzynarodowego należy przystosować pojęcie i praktykę wykonywania suwerenności do potrzeb wynikających z konieczności zapewnienia pokoju i bezpieczeństwa międzynarodowego. Przy tym istotne jest też poszukiwanie sposobów uwzględnienia bezpieczeństwa $\mathrm{w}$ praktyce państw przy poszanowaniu ich suwerenności, która jest podstawa równości praw oraz gwarancja dobrowolności przy zawieraniu umów międzynarodowych.

\section{BEZPIECZEŃSTWO ZBIOROWE A SUWERENNOŚĆ}

Choć pojęcia bezpieczeństwa i suwerenności wydają się zupełnie odrębnymi zagadnieniami, to $\mathrm{w}$ praktyce sa one ze soba powiązane, aby bowiem system bezpieczeństwa zbiorowego mógł powstać i należycie funkcjonować dla dobra wspólnego, jego uczestnicy musza pójść na daleko idący kompromis na płaszczyźnie politycznej, wojskowej oraz prawnej. Znacznie upraszczając to zagadnienie, można stwierdzić, że nie ma suwerenności bez bezpieczeństwa, a bezpieczeństwo zbiorowe jest konsekwencją ograniczenia suwerenności. Oznacza to, że państwa członkowskie systemu bezpieczeństwa zbiorowego muszą uwzględnić konieczność ograniczenia wykonywania suwerenności, co jest warunkiem niezbędnym do powstania ponadnarodowego organu, którego rolą będzie wykonywanie zadań dla właściwego funkcjonowania doktryny wspólnej obrony państw w ramach zinstytucjonalizowanego systemu. Wymaga to więc od nich również rewidowania ich podejścia do kwestii suwerenności.

Zagadnienie suwerenności stanowi fundament i istotę podmiotowości prawnomiędzynarodowej państw. To ono również jest głównym hamulcem lub

${ }^{16}$ Według C. Chaumont: „,'est désir et non pas réalité, que de faire de la souveraineté soit un concept sacré, soit un concept disparu”. Pojawienie się pojęcie suwerenności ma długą i burzliwą historię, sięga bowiem czasów powstania niezależnych grup ludzkich, z władzą najwyższą czy to indywidualną lub zbiorową. Na przestrzeni wieków pojęcie to przyjmowało jednocześnie różne konotacje i odmienne brzmienie w zależności od kontekstu i celów tych, którzy je stosowali. Waga tematyki poruszanej w tym artykule wymaga uprzywilejowania abstrakcyjnej koncepcji pojęcia suwerenności, by w ten sposób wyeliminować niektóre jego znaczenia zawarte w nauce prawa i wykazać, że w prawie międzynarodowym pojęcie suwerenności oznacza podkreślenie ekskluzywnego miejsca w międzynarodowym porządku prawnym. Suwerenność jest pojęciem abstrakcyjnym, szeroko używanym w różnych kontekstach. Jak wszystkie pojęcia podstawowe życia społecznego suwerenność jest określeniem nieprecyzyjnym. Według K. Benyekhlefa: ,c'est une notion »plurielle«, »fluide«, »insaisissable«, »dynamique«, »évolutive«”. W związku z tym pojęcie to powoduje niezliczone i nieustanne kontrowersje teorytyczne i doktrynalne. Aby podkreślić jego dwuznaczny charakter, L. Henkin pisze, że: ,,sovereignty is a bad word, not only because it has served terrible national mythologies; in international relations, and even in international law, it is often a catchword, a substitute for thinking and precision. It means many things, some essential, some insignificant; some agreed, some controversial; some that are not warranted and should not be accepted" (L. Henkin, International Law: Politics, Values and Functions: General Course on Public International Law, „Revue canadienne de droit international” 216, 1989, s. 24-25). 
przeszkodą w tworzeniu bardziej harmonijnego i funkcjonalnie bardziej skutecznego zbiorowego systemu bezpieczeństwa. Globalizacja współczesnego świata, rozumiana jako daleko idące wzajemne powiązania o charakterze politycznym, społecznym, gospodarczym i kulturalnym między państwami, $\mathrm{z}$ jednej strony, a rosnąca $\mathrm{w}$ siłę współczesna doktryna, określana mianem odpowiedzialności za ochronę - z drugiej sprawiają, że konieczna jest redefinicja pojęcia suwerenności ${ }^{17}$. Trudno również mówić o suwerenności państw, gdy następuje podporządkowanie światowym mocarstwom słabszych państw $\mathrm{w}$ zamian za gwarancje bezpieczeństwa ${ }^{18}$. Koniec zimnowojennej ery, a wraz z nim napięć pomiędzy różnym stronami nie zlikwidował potrzeby budowy harmonijnego i pełnowartościowego systemu bezpieczeństwa zbiorowego, opartego na zasadzie równości pomiędzy podmiotami uczestniczącymi $\mathrm{w}$ tym systemie $^{19}$. Można więc powiedzieć, że problematyka ta pozostaje aktualna.

System bezpieczeństwa zbiorowego jako zinstytucjonalizowany mechanizm utrzymania międzynarodowego pokoju, bezpieczeństwa i stabilności spowodował zmniejszenie napięć wśród państw tworzących społeczność międzynarodowa. Wiele zostało zrobione $\mathrm{w}$ tym kierunku, aby zapewnić ramy prawne i instytucjonalne prowadzenia działań zmierzających do rozwiązania konfliktów zagrażających pokojowi międzynarodowemu. Kierunek systemu bezpieczeństwa zbiorowego Narodów Zjednoczonych zawsze wyznaczany był przez wielkie światowe mocarstwa, zwłaszcza pięciu stałych członków Rady Bezpieczeństwa ONZ. Inne państwa czuja się zmarginalizowane w zbiorowym systemie bezpieczeństwa, mogą bowiem korzystać z systemu jedynie wtedy, gdy wielka piątka $\mathrm{z}$ rady bezpieczeństwa ONZ dostrzega w tym swój własny interes społeczny, polityczny i gospodarczy. Niemniej jego słabość nie oznacza odrzucenia systemu w całości jako zbędnego. System bezpieczeństwa zbiorowego ONZ pozostaje istotny i potrzebny, ale jego wyraźne wady muszą zostać usunięte, należy również wyznaczyć mu obowiązek zapobiegania rozprzestrzenianiu broni masowego rażenia i terroryzmu, które nie zostały pierwotnie uwzględnione $\mathrm{w}$ funkcjonowaniu systemu bezpieczeństwa zbiorowego.

Kolejna istotna kwestią jest konieczność podejmowania reform zmierzających do powiększenia składu Rady Bezpieczeństwa, tak aby mogła bardziej dbać o interesy polityczne poszczególnych państw w obliczu nowych wyzwań dotyczących bezpieczeństwa międzynarodowego. System bezpieczeństwa zbiorowego zawsze pozostawał idealistyczną koncepcją, która nigdy nie została jednoznacznie określona przez żaden traktat, a zatem może zostać zdominowany przez wielkie mocarstwa w ramach Rady Bezpieczeństwa ONZ. $\mathrm{W}$ związku z tym konieczne jest podjęcie zasadniczych działań w celu budowania zaufania wśród członków Organizacji Narodów Zjednoczonych, aby stworzyć podstawy solidarności i współpracy niezbędnych do zapewnienia

${ }^{17}$ Zob. E. Haliżak, R. Kuźniar, J. Symonides (red.), op. cit.; E. J. Nolan, Global Engagement Cooperation and Security in the 21th Century, Washington, D.C., 1994.

18 Szerzej na ten temat zob. J. E. Nolan, op. cit.

${ }^{19}$ Szerzej na temat okresu zimnej wojny i jego następstw zob. W. Malendowski, Zimna wojna. Sprzeczności, konflikty i punkty kulminacyjne w radziecko-amerykańskiej rywalizacji, Poznań 1994. 
trwałego pokoju i bezpieczeństwa międzynarodowego. Zgodnie $\mathrm{z}$ postanowieniami art. 24 Karty Narodów Zjednoczonych Radzie Bezpieczeństwa powierzono rolę organu odpowiedzialnego za utrzymanie międzynarodowego pokoju i bezpieczeństwa, a wszelkie decyzje podjęte przez Radę są wiążące dla wszystkich członków ONZ, zgodnie z art. 25 Karty. Karta ONZ przewiduje, że działania podjęte przez Radę Bezpieczeństwa w ramach rozdz. VI, art. 33, dotyczące zagadnienia pokojowego regulowania sporów międzynarodowych, mają charakter wyłącznie zaleceń. Natomiast zagrożenia, zakłócenia pokoju lub akty agresji, jak to podkreślono w rozdz. VII Karty, stanowią podstawę do bezwzględnego korzystania z kompetencji Rady. W kwestii utrzymania pokoju i bezpieczeństwa międzynarodowego decyzje Rady Bezpieczeństwa maja pierwszeństwo, tak stanowi art. 103 Karty. A zatem jak można określić związek między bezpieczeństwem międzynarodowym a suwerennością państw? Uznając je za pojęcia przeciwstawne, można jedynie realizować jedno kosztem drugiego, choć wydaje się, że żadne z nich osobno nie gwarantuje w przyszłości w miarę harmonijnego funkcjonowania społeczności międzynarodowej.

Uwzględnianie wymagań bezpieczeństwa międzynarodowego przez ograniczanie wykonywania suwerenności państw może wywołać reakcje, które uniemożliwią lub istotnie utrudnią osiagnięcie celów bezpieczeństwa zbiorowego. $\mathrm{Z}$ drugiej strony preferowanie absolutnej zasady suwerenności kosztem bezpieczeństwa międzynarodowego uniemożliwia lub zasadniczo ogranicza możliwość stawiania czoła wspólnym zagrożeniom, a zwłaszcza zagrożeniom terrorystycznym, i rozwiązanie istotnych spraw rozwojowych. Na szczęście rozstrzygnięcie omawianego dylematu nie jest konieczne. Globalizacja współczesnego świata, wraz z wynikająca z niej daleko idąca współzależnością państw, nie może być traktowana jako zagrożenie suwerenności. Jak pisze Andrzej Wasilkowski: ,„przeciwstawianie suwerenności i współzależności jest sugestywne, lecz chyba mocno uproszczone. Opiera się na utożsamianiu suwerenności z pewnymi jej postaciami historycznymi, jak absolutyzm lub nacjonalizm europejski XIX i XX w. Kto utożsamia suwerenność z takimi jej wcieleniami, musi widzieć $\mathrm{w}$ niej tylko przeszkodę w rozwiązaniu zagadnień wspólnych, wynikających ze współzależności” ${ }^{20}$.

\section{PODSUMOWANIE}

Okres globalizacji i wynikające $\mathrm{z}$ niego związki państw oraz ich współzależność w sferze politycznej, gospodarczej, społecznej i kulturalnej, jak również różnorodność aktorów występujących na arenie międzynarodowej skłaniają do refleksji nad pojęciem suwerenności. System bezpieczeństwa zbiorowego, jako instrument służący dobru wspólnemu w kontekście utrzymania pokoju, bezpieczeństwa i stabilności, jest koncepcją sięgającą daleko

${ }^{20}$ A. Wasilkowski, Suwerenność a wspótzależność, w: I. Michalska (red.), Suwerenność we wspótczesnym prawie międzynarodowym, Warszawa 1991, s. 8-16. 
w przeszłość. Pomimo że koncepcji tej poświęcano szczególną uwagę w różnych okresach historii, to nadal nie straciła ona na aktualności ani też nie znaleziono optymalnego rozwiązania w kwestii skutecznego funkcjonowania systemu. Istota systemu bezpieczeństwa zbiorowego oparta jest na poszukiwaniu właściwej odpowiedzi na kwestie bezpieczeństwa nurtujące społeczność międzynarodową. W odróżnieniu od wewnętrznego porządku prawnego w poszczególnych państwach system prawny, na którym oparte jest bezpieczeństwo zbiorowe, jest ułomny, co przejawia się m.in. brakiem zorganizowanego aparatu przymusu i jednolitego systemu sankcyjnego, a skutkuje trudnościami w tworzeniu harmonijnego i efektywnego systemu bezpieczeństwa zbiorowego, opartego na równości pomiędzy suwerennymi podmiotami wchodzącymi w jego skład. Niemniej należy również podkreślić, że prawidłowe funkcjonowanie zbiorowego systemu bezpieczeństwa wymaga nie tylko procedury dostosowanej do aktualnej sytuacji międzynarodowej, lecz także środków materialnych, za pomoca których rozwiązywane są spory powstałe między państwami. $\mathrm{W}$ tym artykule podkreślono powagę kwestii bezpieczeństwa zbiorowego zarówno w kontekście utrzymania pokoju, bezpieczeństwa i stabilności, jak i rozwijania stosunków politycznych, gospodarczych, społecznych i kulturalnych między państwami. Należy również zauważyć, że koniec okresu zimnowojennego w żaden sposób nie spowodował zniknięcia zagrożeń i napięć między poszczególnym podmiotami w stosunkach międzynarodowych.

W procesie utrzymania pokoju i bezpieczeństwa międzynarodowego istotna rolę odgrywają organizacje międzynarodowe, zarówno na szczeblu regionalnym, jak i ogólnoświatowym. Następuje to właśnie dzięki przekazaniu przez państwo części swojej kompetencji. W literaturze przedmiotu w sposób jednoznaczny podkreśla się udziału organizacji międzynarodowych w budowie zarówno struktur systemu bezpieczeństwa zbiorowego, jak również systemu samoobrony zbiorowej. Rozdział VIII Karty Narodów Zjednoczonych stanowi punkt wyjścia analizy problematyki relacji pomiędzy organizacją uniwersalną a organizacjami regionalnymi, zarówno $\mathrm{w}$ sensie doktrynalnym, jak i praktyki międzynarodowej ${ }^{21}$. Rozdział ten jest punktem odniesienia dla państw i innych instytucji przy podejmowaniu debaty $\mathrm{w}$ kwestii utrzymania pokoju i bezpieczeństwa międzynarodowego, chociaż niejednokrotnie Rada Bezpieczeństwa ONZ omija postanowienia rozdziału VIII Karty, zwłaszcza w sprawach związanych z rozwiązywaniem konfliktów na kontynencie afrykańskim.

Relacje pomiędzy organizacją uniwersalną a organizacjami regionalnymi istniały od początku ukształtowania się uniwersalnego systemu bezpieczeństwa zbiorowego, jednak powstał również dylemat, czy należy uprzywilejować system uniwersalny, czy raczej dążyć do równego podziału zadań między organizacja uniwersalną a instytucjami regionalnymi. Zasadnicze różnice pomiędzy uniwersalizmem a regionalizmem przedstawione $\mathrm{w}$ momencie budowy Ligii

${ }^{21}$ Zob. A. Abass, The United Nations, the African Union and the Darfur Crisis: Of Apology and Utopia, „Netherlands International Law Review” 54, 2007, s. 415-440; Regional Organizations and the Developpement of Collective Security: Beyond Chapter VII of the UN Charter, Oxford 2004; J. Cardona Liorens, op. cit., s. 251-289. 
Narodów, a następnie po jej powstaniu ujawniły się również podczas tworzenia Organizacji Narodów Zjednoczonych. Propozycje z Dumbarton Oaks przedstawione przez państwa alianckie zostały przyjęte podczas konferencji w San Francisco i ujęte w postanowieniach art. 52 i 53 Karty Narodów Zjednoczonych. Państwa alianckie, mając na uwadze złożoność Paktu Ligii Narodów, jeżeli chodzi o rozwiązanie kwestii relacji pomiędzy organizacjami regionalnymi a Liga, postanowiły zapewnić kompetencję wyłączną Rady Bezpieczeństwa ONZ, która w pełni kontroluje kwestie dotyczące utrzymywania pokoju i bezpieczeństwa międzynarodowego. Tym samym porozumienia regionalne nie miały możliwości przejęcia odpowiedzialności w pierwszej kolejności za konflikty lokalne oraz znalezienia właściwego środka pokojowego do ich rozwiązywania. W ten sposób uzależniły się całkowicie od Rady Bezpieczeństwa ONZ, jeżeli chodzi o stosowanie środków przymusu.

Jednakże reakcja większości uczestników konferencji w San Francisco w obliczu uniwersalistycznego posunięcia była negatywna (np. państwa Ameryki Południowej życzyły sobie w szczególności utrzymania autonomii panamerykańskiego systemu regionalnego, wzmocnionego przez Akt z Chapultepec, przyjęty w 1945 r.). Poza tym uznano również całkowite uzależnienie porozumień regionalnych od woli Rady Bezpieczeństwa ONZ w kwestiach dotyczących zastosowanie środków przymusu w sytuacjach konfliktowych, co powoduje paraliż systemu utrzymania pokoju i bezpieczeństwa międzynarodowego, zwłaszcza w wypadku stosowania prawa weta przez mocarstwa. W związku z tym znaleziono kompromis uwzględniający zarówno sprzeciw, jak i prośbę dotyczące autonomii instytucji regionalnych i ewentualne omijanie blokady Rady Bezpieczeństwa ONZ, nie rezygnując z pierwszeństwa systemu uniwersalnego. Przyjęte rozwiązanie uwzględnia - z jednej strony - regionalne sposoby pokojowego regulowania sporów (art. 52), nawiązując do art. 33 par. 1 Karty oraz namawiając państwa do rozwiązywania sporów lokalnych w ramach porozumień regionalnych (art. 52, par. 2), z drugiej - utrzymuje monopol Rady Bezpieczeństwa $\mathrm{w}$ podejmowaniu decyzji o stosowaniu środków przymusu (art. 53), ale równocześnie łagodzi go przez uznanie prawa do samoobrony zbiorowej, które nie jest objęte wcześniejszą kontrolą Rady (art. 51). W związku z powyższym można stwierdzić, że treść rozdz. VIII Karty wyraźnie sugeruje współpracę wprowadzoną przez określone zasady pomiędzy ONZ a organizacjami regionalnymi lub subregionalnymi działającymi w dziedzinie utrzymania pokoju i bezpieczeństwa międzynarodowego.

dr Boubacar Sidi Diallo

Uniwersytet im. Adama Mickiewicza $w$ Poznaniu

diallo@amu.edu.pl 


\section{COLLECTIVE SECURITY AND STATE SOVEREIGNTY}

\section{Summary}

The subject of these reflections on the contemporary international relations is, on the one hand, sovereignty and, on the other, international security, and the analysis of the relationship between the system of collective security and the sovereignty of states in the context of sustainable peace and stability in the world. States have traditionally been tied to the idea of sovereignty. However, among the most characteristic features of the international relations of our time is the growing number of various types of threats originating in states (e.g. Iran, North Korea), in organisations or other entities (e.g. al-Qaeda).

Security and sovereignty are two basic concepts most commonly discussed in literature and international legal doctrine. There are two reasons for that: (i) firstly, the main actors in international relations are states which are sovereign entities and the relations or cooperation between them is based on respect for the principle of that sovereignty, and (ii) secondly, the issue of safety is a key issue and a prerequisite for the performance of fully sovereign rights of these countries, necessary to ensure international cooperation and socio-economic development. This paper discusses the need to institutionalise legitimate use of force in global organisations as well as in their regional structures, and to rapidly and effectively manage situations and conflicts intercept to international peace and security. It also draws special attention to the role and place of international organisations in the maintenance of international peace and security both, at universal, and regional level. 
Copyright of Journal of Law, Economics and Sociology is the property of Faculty of Law and Administration of Adam Mickiewicz University in Poznan and its content may not be copied or emailed to multiple sites or posted to a listserv without the copyright holder's express written permission. However, users may print, download, or email articles for individual use.

Właścicielem praw autorskich do „Ruchu Prawniczego, Ekonomicznego i Socjologicznego” jest Wydział Prawa i Administracji Uniwersytetu im. Adama Mickiewicza w Poznaniu. Zawartość czasopisma nie może być kopiowana, przesyłana do innych stron internetowych bądź zamieszczana na blogach bez pisemnej zgody wydawcy. Niemniej artykuły można drukować, kopiować lub przesyłać w formie elektronicznej na własny użytek. 